\title{
New records of lichens from the Russian Far East. I. Fuscidea submollis and other arctic-alpine species
}

\author{
L. S. Yakovchenko', E. A. Davydov², A. G. Paukov³, Y. Ohmura ${ }^{4}$ \\ ${ }^{1}$ Federal Scientific Center of the East Asia Terrestrial Biodiversity FEB RAS, Vladivostok, 690022, Russian Federation. \\ E-mail: lidiyakovchenko@mail.ru \\ ${ }^{2}$ Altai State University, Lenina Avenue, 61, Barnaul, 656049, Russian Federation. E-mail: eadavydov@yandex.ru \\ ${ }^{3}$ Institute of Natural Sciences and Mathematics, Ural Federal University, Lenina Avenue, 51, Ekaterinburg, 620000, \\ Russian Federation: E-mail: alexander_paukov@mail.ru \\ ${ }^{4}$ Department of Botany, National Museum of Nature and Science, 4-1-1 Amakubo, Tsukuba, Ibaraki, 305-0005, Japan. \\ E-mail: ohmura-y@kahaku.go.jp
}

Keywords: Asia, biogeography, Fuscideaceae, saxicolous lichen community, South Siberia.

Summary. Fuscidea submollis Mas. Inoue is reported for the first time from the Russian Far East. Distinctive features of the taxon are discussed, and a comparison with known saxicolous Fuscidea V. Wirth \& Vězda species with amyloid medulla is made. Three arctic-alpine species: Sporastatia testudinea (Ach.) A. Massal., Buellia concinna Th. Fr., Amygdalaria panaeola (Ach.) Hertel et Brodo, and Aspilidea myrinii (Fr.) Hafellner are recorded for the first time in the South Far East from the Sikhote Alin Range (Primorye Territory). Calvitimela aglaea (Sommerf.) Hafellner is reported for the first time from Sikhote Alin Range and Primorye Territory.

\section{Новые находки лишайников на Дальнем Востоке России. I. Fuscidea submollis и другие арктоальпийские виды}

\author{
Л. С. Яковченко ${ }^{1}$ Е. А. Давыдов², А. Г. Пауков ${ }^{3}$, Й. Омура $^{4}$ \\ ${ }^{I}$ Федеральный научный центр биоразнообразия наземной биоты Восточной Азии ДВО РАН, пр. Столетия \\ Владивостока, 159, г. Владивосток, 690022, Россия \\ ${ }^{2}$ Алтайский государственный университет, пр. Ленина, 61, г. Барнаул, 656049, Россия
}

${ }^{3}$ Институт естественных наук и математики, Уральский федеральный университет, пр. Ленина, 51, Екатеринбург, 620000, Россия

${ }^{4}$ Отдел ботаники, Начиональный музей природы и науки, 4-1-1 Амауибо, г. Цукуба, Ибараки, 305-0005, Япония

Ключевые слова: Азия, биогеография, эпилитные лишайниковые сообщества, Южная Сибирь, Fuscideaceae.

Aннотация. Fuscidea submollis приводится впервые для российского Дальнего Востока. Обсуждаются отличия таксона от близких видов и сравнение с известными эпилитными видами рода Fuscidea с амилоидной сердцевиной. Четыре арктоальпийских вида: Sporastatia testudinea (Ach.) A. Massal., Buellia concinna Th. Fr., Amygdalaria panaeola (Ach.) Hertel et Brodo, Aspilidea myrinii (Fr.) Hafellner впервые отмечены для юга Приморья с Сихотэ-Алиня (Приморский край). Calvitimela aglaea (Sommerf.) Hafellner приводятся впервые для Сихотэ-Алиня и Приморского края. 


\section{Introduction}

The Eastern Asiatic floristic region is one of the prominent centers of biodiversity and endemism, which is characterised by an exceptionally large number of endemic genera of higher plants (Takhtajian, 1986). Despite the fact that the first papers on lichens of Russian Far East had been issued in the beginning of the XX century, the systematic research of the diversity of lichens of this territory has begun only in the 1970-s. The study was started by L. A. Knyazheva in the 1969 and resulted in a publication of a list of lichens contained 222 species (Knyazheva, 1973). A checklist of lichens of Primorye Territory with 752 species was issued 29 years later (Tchabanenko et al., 2002). Having summarized literature data and results of her own research, in the same year Tchabanenko (2002) published a list of lichens and lichenophylous fungi of the South of the Russian Far East. After compiling new data issued between 2002 and 2010, G. Urbanavichus (2010) published a list of 1107 species, 206 of which were known from the Southern part of Far East only. The author noted (Urbanavichus, 2011) that Far East was a one of the territories of Russia, where the knowledge of lichen biodiversity was very insufficient. The least known group is saxicolous species that grow in high elevations. The aim of our study was to make a supplement to the data on diversity of lichens of the Southern part of Russian Far East.

Genus Fuscidea V. Wirth \& Vězda (Fuscideaceae) includes 35 species (Wijayawardene et al., 2017) growing on siliceous rocks and bark and distributed from moderate elevations to high mountains and Arctic. The diagnostic characters of the genus are crustose thallus with a brownish hypothallus, lecideoid apothecia with black to brown-black discs, a proper margin that is paler than the discs, brown epyhymenium and excipulum, green coccoid alga, slightly tapered or cylindrical-clavate asci of the Fuscidea-type and ellipsoid to globose, oblong or bean-shaped, simple to one-septated ascospores, which are colorless and becoming brownish with the age (Fryday, 2008). Eighteen species of Fuscidea were reported for Russia (Urbanavichus, 2010; Stepanchikova et al., 2017; Chesnokov et al., 2018).

During the preparation of this paper the first record of Fuscidea submollis Mas. Inoue in Russia from Kodar (South Siberia) was published (Chesnokov et al., 2018), but the data were insufficient and contained only the information on the label and the TLC results. Here we report the second record of the species in Russia and its first record from the Russian Far East integrated with the detailed information on the species and a comparison with closely related taxa. In addition, here we represent the findings of four widely distributed arctic-alpine species, i.e. Amygdalaria panaeola (Ach.) Hertel et Brodo, Aspilidea myrinii (Fr.) Hafellner, Buellia concinna Th. Fr., Calvitimela aglaea (Sommerf.) Hafellner, and Sporastatia testudinea (Ach.) A. Massal., which have not been previously reported from the Sikhote Alin Range (South Far East).

\section{Materials and methods}

The specimens examined are deposited in the herbarium of the Altai State University (ALTB) and Ural Federal University (UFU). Morphological observations were made using a dissecting microscope. Cross-sections of apothecia and thalli were made by hand with a razor blade and observed after mounting in water. Lichen substances of some species were studied by spot-tests using potassium hydroxide solution (K), sodium hypochlorite solution (C), 1,4-Phenylendiamine (Pd), and iodine (I), and by thin-layer chromatography (TLC) in solvent systems A and B (Orange et al., 2001).

\section{Results}

\section{Species new for the Far East of Russia}

\section{Fuscidea submollis Mas. Inoue (Fig. 1B)}

Thallus epruinose, bullate- to verrucose-areolate, brownish ash-gray, areoles up to $1 \mathrm{~mm}$ in diam., continuous in the center and dispersed at periphery of the thallus, with black prothallus, medulla I+ intensive violet. Apothecia up to $1 \mathrm{~mm}$ in diam., on areoles, appressed (disc on the same level with the thallus or slightly higher), adnate to slightly constricted at the base, disc black, plane, epruinose to thinly pruinose, proper margin thin and flexuous, black, persistent to rarely excluded. Hymenium 50-70 $\mu \mathrm{m}$ tall, asci bullate to cylindrical, Fuscideatype, 45-55 × 10-13 $\mu \mathrm{m}$. Ascospores are colorless to brownish at maturity, ellipsoid, 7.5-10 $\times 5-6 \mu \mathrm{m}$. Conidia baciliform, 3.5-4 × $1.5 \mu \mathrm{m}$.

Thallus and medulla $\mathrm{K}-, \mathrm{C}-, \mathrm{KC}-, \mathrm{Pd}-$. TLC: divaricatic acid.

Specimens examined: "Russia, Primorye Territory, Chuguevsky District, Sikhote-Alin Range, at $900 \mathrm{~m} \mathrm{SW}$ from the top of the Snezhnaya Mt., stonefield, N4343'52", E134'25'37", elev. $1450 \mathrm{~m}$ a. s. 1., on stones. 8 VIII 2014. E. A. Davydov 17901, L. S. Yakovchenko" (ALTB). 


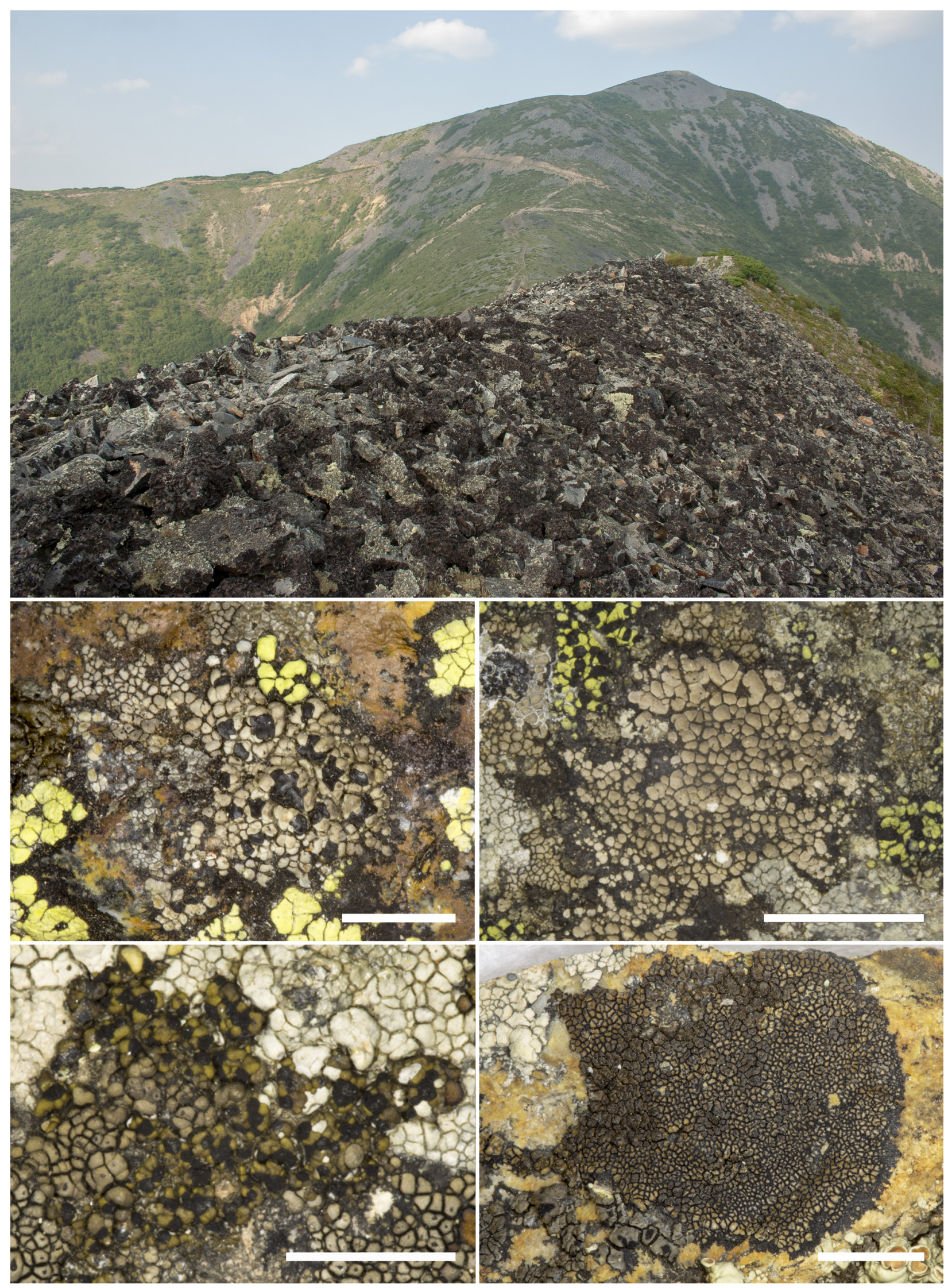

Fig. 1. A - habitat of arctic-alpine species of lichens at Snezhnaya Mt. B - Fuscidea submollis Mas. Inoue. Scale = $0.5 \mathrm{~cm} . \mathrm{C}-$ Amygdalaria panaeola (Ach.) Hertel et Brodo. Scale $=0.5 \mathrm{~cm} . \mathrm{D}-$ Buellia concinna Th. Fr. Scale $=0.5$ cm. E - Sporastatia testudinea (Ach.) A. Massal. Scale $=0.5 \mathrm{~cm}$. All photos: E. A. Davydov. 
Specimens of Fuscidea submollis from Far East agree well with the protologue (Inoue, 1981). According to our observations, the inner part of excipulum is $\mathrm{I}+$ blue in specimens from Sikhote Alin. This reaction was not noted in the protologue. In the Russian Far East Fuscidea submollis occurs at elevation $1450 \mathrm{~m}$ a. s. 1. in alpine community on hard siliceous rocks with Anamylopsora pulcherimma (Vain.) Timdal, Protoparmelia badia (Hoffm.) Hafelner, Tephromela atra (Huds.) Hafellner, Acarospora fuscata (Schrad.) Th. Fr., Melanelia stygia (L.) Essl., Montanelia tominii (Oxner) Divakar et al., Lecanora marginata (Schaer.) Hertel et Rambold, Rhizocarpon geographicum (L.) DC., $R$. viridiatrum (Wulfen) Körb and others.

\section{Species new for the South of Far East of Russia}

\section{Amygdalaria panaeola (Ach.) Hertel et Brodo (Fig. 1C)}

Specimens examined: "Russia, Primorye Territory, Chuguevsky District, Sikhote-Alin Range, the top of the Oblachnaya Mt., N43 $41^{\prime} 39^{\prime \prime}$, E134'11'55", elev. $1800-1854 \mathrm{~m}$ a. s. 1., on stones. 10 VIII 2014. E. A. Davydov 17902, L. S. Yakovchenko" (ALTB).

Amygdalaria panaeola is a widely distributed circumpolar artic-alpine species (Brodo, Hertel, 1987). In Russia it was reported almost from all mountain regions; in the Russian Far East it was previously known from its northern parts and the Arctic (Urbanavichus, 2010). The species is reported from central Japan (Ohmura, Kashiwadani, 2018).

Aspilidea myrinii (Fr.) Hafellner

Specimens examined: "Russia, Primorye Territory, Chuguyevskiy district, 'Zov Tigra' National park, Oblachnaya mountain, N4340'35.2', E134¹1'59.0", elev. $1621 \mathrm{~m}$ a. s. 1., on rock debris with Pinus pumila vegetation, on rock. 10 VIII 2014. A. G. Paukov 3182” (UFU).

Aspilidea myrinii is an arctic-alpine, circumpolar species, which prefers acid siliceous rocks. In Eurasia it is widespread in the Alps (Nimis et al., 2018), Fennoscandia (Nordin et al., 2011), European Russia, Southern Siberia and the Arctic part of Russian Far East (Urbanavichus, 2010). The genus belongs to Ostropomycetidae, genera incertae sedis (Wijayawardene et al., 2018), however a recent phylogenetic analysis (Wheeler, 2017) places it into Megasporaceae with a high support. The specimens have thick thalli with convex, lightgrey to yellowish-grey areoles, black, immersed apothecia with a poorly visible black margin. The thalli contain norstictic acid. They can be confused with norstictic acid-containing species of Aspicilia A. Massal., but differs by the I+ blue medulla, short conidia and a yellowish color of thalli.

Buellia concinna Th. Fr. (Fig. 1D)

Specimens examined: "Russia, Primorye Territory, Chuguevsky District, Pogranichnyi range, at $15 \mathrm{~km} \mathrm{~S}$ from the Komissarovo settlement near the top of Siniaya Mt., N44 $51^{\prime} 37.5^{\prime \prime}$, E131 ${ }^{\circ} 42^{\prime} 34^{\prime \prime}$, elev. $650 \mathrm{~m}$ a. s. 1., on rock outcrops. 3 VIII 2014. E. A. Davydov 17903, L. S. Yakovchenko» (ALTB).

The material of Buellia concinna from Far East has I- medulla and $\mathrm{K}$ - thallus. It is an arctic-alpine species widely distributed predominantly in the Nothern Hemisphaere (Scheidegger, Ruef, 1988; Bungartz et al., 2004). In Russia it was previously known from the Arctic, northern part of European Russia, South Siberia and Arctic part of the Russian Far East (Urbanavichus, 2010). 1E)

Sporastatia testudinea (Ach.) A. Massal. (Fig.

Specimens examined: "Russia, Primorye Territory, Chuguevsky District, Sikhote-Alin' Range, at $900 \mathrm{~m} \mathrm{SW}$ from the top of the Snezhnaya Mt., stone-

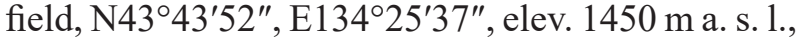
on stones. 8 VIII 2014. E. A. Davydov 17904, L. S. Yakovchenko" (ALTB).

Sporastatia testudinea is a widely distributed species throughout the Northern Hemisphere and is scattered in the Southern Hemisphere on subantarctic islands and in southern South America (Grube, Poelt, 1993; Thomson, 1997; Gilbert, Coppins, 2009; Yakovchenko, Davydov, 2018). In Russia the species is reported from all main mountain ranges; in the Russian Far East it was previously known from its northern and Arctic parts (Urbanavichus, 2010). The species is reported for central Japan (Inoue et al., 2007).

\section{Species new for the Sikhote Alin Range}

\section{Calvitimela aglaea (Sommerf.) Hafellner}

Specimens examined: "Russia, Primorye Territory, Chuguevsky District, Sikhote Alin Range, at $15 \mathrm{~km}$ SE from the Yasnoye settlement, N43 $36^{\prime} 17^{\prime \prime}, \mathrm{E} 134^{\circ} 06^{\prime} 30^{\prime \prime}$, elev. $540 \mathrm{~m}$ a. s. 1., on stones. 6 VIII 2014. E. A. Davydov 16750, L. S. Yakovchenko" (ALTB); "Sikhote Alin Range, at 900 $\mathrm{m} \mathrm{SW}$ from the top of the Snezhnaya Mt., stonefield, N4343'52", E134'25'37", elev. 1450 m a. s. 1., on stones. 8 VIII 2014. E. A. Davydov 17905, L. S. Yakovchenko" (ALTB). 
Calvitimela aglaea is a widely distributed circumpolar artic-alpine species (Hertel, Rambold, 1985). In Russia it was reported from almost all mountain regions (except Caucasus). In the Russian Far East it was previously known from its northern and Arctic parts (Urbanavichus, 2010).

\section{Discussion}

Excepting Fuscidea submollis, 6 saxicolous Fuscidea species with amyloid medulla are known worldscale: Fuscidea aleutica (Degel.) Fryday, F. impolita (Müll. Arg.) Hertel, F. lowensis (H. Magn.) R. Anderson et Hertel, F. thomsonii Brodo et V. Wirth, F. umbricolor (Nyl.) Hertel, and F. gothoburgensis (H. Magn.) V. Wirth et Vězda. The last one has normally negative reaction with I, but sometimes medulla is I+ blue. All species are well distinguished from Fuscidea submollis: F. aleutica described and known from North America possess thinner, brown, cracked-areolate thallus with plane areoles; apothecia of $F$. aleutica are adnate like those of F. submollis, but smaller in two times with longer asci $(75-85 \mu \mathrm{m})$ and wider ascospores (up to $7 \mu \mathrm{m}$ thick). Fuscidea thomsonii scattered and distributed in North America differs from $F$. submollis by having a pale grey to greyish-brown, cracked-areolate thallus and innate apothecia with proper margin paler than the disc. North American species Fuscidea lowensis is similar to F. submollis possessing a verrucose areolate thallus on black prothallus, but in contrast of $F$. submollis, thallus of $F$. lowensis is dark brown, often with a grey pruina and apothecia are sessile and constricted below with dark-brown to red-brown hypothecium; spores subglobose, thicker (6-7 $\mu \mathrm{m}$ thick). Subantarctic species Fuscidea impolita differs by its thinner thallus and apothecia with only a lateral exciple; also it is anatomically distinct in having more robust paraphyses with a darker pigmented cap and with much shorter asci (25-30 $\mu \mathrm{m}$ long). Fuscidea umbricolor known only from South America (Colombia) differs from F. submollis by having smaller apothecia (up to $0.5 \mathrm{~mm}$ in diam.) permanently constricted at the base and indistinct hypothecium. Fuscidea gothoburgensis (known from Europe and North America) than it has amyloid medulla is clearly distinct and differ from $F$. submollis by having soralia.

From the morphologically closest species Fuscidea mollis, F. submollis is distinguished by its amyloid medulla and bullate- to verrucose-areolate thallus with adpressed-adnate apothecia, while $F$. mollis is characterized by a smooth, finely cracked areolate thallus with flat and contiguous areoles, medulla I-, and sessile apothecia. In addition, both species differ by distribution: while $F$. mollis has wide Holarctic area (has been recorded from Europe, Asia, North America and Arctic), Fuscidea submollis until recently has been considered as an endemic species for Japan (Shimizu, 2004; Ohmura, Kashiwadani, 2018). It is reported now from two localities in Asian Russia: South Siberia (Kodar range) (Chesnokov et al., 2018) and South Far East (Sikhote Alin Range). There are only few saxicolous species with a similarly confined Far East Asian-East Siberian distribution area, e.g. Umbilicaria formosana Frey, U. kisovana (Zahlbr. ex Asahina) Zahlbr., Boreoplaca ultrafrigida Timdal, Parmelia shinanoana Zahlbr. (Davydov, Wei, 2009; Davydov et al., 2019).

Arctic-alpine species Sporastatia testudinea, Buellia concinna, Aspilidea myrinii, Calvitimela aglaea, and Amygdalaria panaeola are recorded for the first time from South part of Russian Far East. All records were found at the elevation ca. 1450-1800 m a. s. 1. on hard siliceous rocks (Fig. 1A), except Buellia concinna, which parasites on Rimularia sp. at lower elevation.

All species, but Buellia concinna, were recorded for Japan (Ohmura, Kashiwadani, 2018).

\section{Acknowledgements}

The reported study was funded by RFBR and JSPS according to the research project № 19-5450010.

\section{REFERENCES}

Brodo I. M., Hertel H. 1987. The lichen genus Amygdalaria (Porpidiaceae) in North America. Herzogia 7(3-4): $493-521$.

Bungartz F., Elix J. A., Nash T. H. III. 2004. The genus Buellia sensu lato in the Greater Sonoran Desert Region: saxicolous species with one-septate ascospores containing xanthones. Bryologist 107(4): 459-479. DOI: 10.1639/0007-2745(2004)107

Chesnokov S., Konoreva L., Paukov A. 2018. New species and records of saxicolous lichens from the Kodar Range (Trans-Baikal Territory, Russia). Plant and Fungal Systematics 63(1): 11-21. DOI: 10.2478/pfs-2018-0003

Davydov E. A., Chesnokov S. V., Konoreva L. A., Andreev M. P. 2019. Species of the family Umbilicariaceae (lichenized Ascomycota) from the Stanovoye Nagor'e Highlands (South Siberia, Russia). Herzogia 32(2). In press. 
Davydov E. A., Wei J.-C. 2009. Boreoplaca ultrafrigida (Umbilicariales), the correct name for Rhizoplacopsis weichingii. Mycotaxon 108: 301-305. DOI: abs/10.1639/0007-2745.115.1.61.

Fryday A. M. 2008. The genus Fuscidea (Fuscideaceae, lichenized Ascomycota) in North America. Lichenologist 40(4): 295-328. DOI: 10.1017/s0024282908007755

Gilbert O. L., Coppins B. J. 2009. Sporastatia Massal. In: The Lichens of Great Britain and Ireland. Eds. C. W. Smith, A. Aptroot, B. J. Coppins, A. Fletcher, O. L. Gilbert, P. W. James et P. A. British Lichen Society, London, 850 pp.

Grube M., Poelt J. 1993. Beiträge zur Kenntnis der Flechtenflora des Himalaya X. Sporastatia testudinea, ihre Variabilität, ihre Ökologie und ihre Parasiten in Hochasien. Fragmenta Floristica et Geobotanica Supplementum 2: $113-122$.

Hertel H., Rambold G. 1985. Lecidea sect. Armeniacae: lecideoide Arten der Flechtengattungen Lecanora und Tephromela (Lecanorales). Botanische Jarbucher fur Systematik 107(1-4): 469-501.

Inoue M. 1981. A taxonomic study of the Japanese species of Fuscidea (lichens). Hikobia Supplement 1: 161-176. Inoue M., Kashiwadani H., Moon K. H. 2007. Alpine lecideoid lichens from southern part of Mts. Akaishi, central Japan. Memoirs of the Faculty of Education and Human Studies Akita University (Natural Science) 62: 9-17.

Knyazheva L. A. 1973. Lichens of the south of Primorsky Krai. Komarovskiye Chteniya 20: 34-46 [In Russian]. (Княжева Л. А. Лишайники юга Приморского края // Комаровские чтения. Владивосток, 1973. Вып. 20. С. 34-46).

Nimis P. L., Hafellner J., Roux C., Clerc P., Mayrhofer H., Martellos S., Bilovitz P. O. 2018. The lichens of the Alps - An annotated checklist. MycoKeys 31: 1-634.

Nordin A., Moberg R., Tonsberg T., Vitikainen O., Dalsätt A., Myrdal M., Snitting D., Ekman S. Santesson's Checklist of Fennoscandian Lichen-forming and Lichenicolous Fungi. Ver. April 29, 2011. URL: http://130.238.83.220/ santesson/home.php (Accessed 10 May 2019).

Ohmura Y., Kashiwadani H. 1997. Lichens of Mt. O-akan and its adjacent areas, Hokkaido, Japan. Bulletin of the National Science Museum, Series B 23: 1-24.

Ohmura Y., Kashiwadani H. 2018. Checklist of lichens and allied fungi of Japan. National Museum of Nature and Science Monographs 49: 1-140.

Orange A., James P. W., White F. J. 2001. Microchemical methods for the identification of lichens. British Lichen Society, $101 \mathrm{pp}$.

Scheidegger C., Ruef B. 1988. Die xanthonhaltigen, gesteinsbewohnenden Sippen der Flechtengattung Buellia De Not. (Physciaceae, Lecanorales) in Europa. Nova Hedwigia 47(3-4): 433-468.

Shimizu A. 2004. Community structure of lichens in the volcanic highlands of Mt. Tokachi, Hokkaido, Japan. Bryologist 107: 141-151.

Stepanchikova I. S., Andreev M. P., Himelbrant D. E., Motiejūnaitè J., Schiefelbein U., Konoreva L. A., Ahti T. 2017. The lichens of bolshoy tuters island (Tytärsaari), Leningrad region, Russia. Folia Cryptogamica Estonica 54: 95-116. DOI: 10.12697/fce.2017.54.14

Takhtajan A. L. 1986. Floristic regions of the world. University of California Press, Berkeley, 522 pp.

Tchabanenko S. I. 2002. Konspekt flory lishaynikov yuga rossiyskogo Dalnego Vostoka [Synopsis of lichen flora of the South of the Russian Far East]. Dalnauka, Vladivostok, 231 pp. [In Russian]. (Чабаненко С. И. Конспект флоры лишайников юга российского Дальнего Востока. Владивосток: Дальнаука, 2002. 231 с.).

Tchabanenko S. I., Skirina I. F., Knyazheva L. A. 2002. Spisok lishaynikov Primorskogo kraya i obitayushchikh na nikh gribov [A list of lichens and lichenicolous fungi of Primorsky Krai]. Yuzhno-Sakhalinsk, 89 pp. [In Russian]. (Чабаненко С. И., Скирина И. Ф., Княжева Л. А. Список лишайников Приморского края и обитающих на них грибов. Южно-Сахалинск, 2002. 89 с.).

Thomson J. W. 1997. American Arctic Lichens. 2. The Microlichens. The University of Wisconsin Press, Madison, $675 \mathrm{pp}$.

Urbanavichus G. P. 2010. Spisok lichenoflory Rossii [A checklist of the lichen flora of Russia]. Nauka, St. Petersburg, 194 pp. [In Russian]. (Урбанавичюс Г. П. Список лишайников России. СПб.: Наука, 2010. 194 с.).

Urbanavichus G. P. 2011. Specific features of lichen diversity of Russia. Izvestiya RAN. Seriya geograficheskaya 1: 66-78 [In Russian]. (Урбанавичюс Г. П. 2011. Особенности разнообразия лихенофлоры России // Известия РАН, сер. Географическая. Т. 1. С. 67-78).

Wijayawardene N. N., Hyde K. D., Lumbsch H. T., Liu J. K., Maharachchikumbura S. S. N., Ekanayaka A. H., Tian Q., Phookamsak R. 2018. Outline of Ascomycota: 2017. Fungal Diversity 88: 167-263.

Wijayawardene N. N., Hyde K. D., Rajeshkumar K. C., Hawksworth D. L., Madrid H., Kirk P. M., Braun U., Singh R. V., Crous P. W., Kukwa M. et al. 2017. Notes for genera: Ascomycota. Fungal Diversity 86: 1-594.

Wheeler T. B. 2017. Multilocus phylogeny of the lichen family Megasporaceae. Graduate Student Theses, Dissertations, and Professional Papers. 11077. URL: https://scholarworks.umt.edu/etd/11077

Yakovchenko L. S., Davydov E. A. 2018. Sporastatia crassulata, a new species from the Altai Mountains with a key to Sporastatia and remarks on some additional species. Lichenologist 50(4): 439-450. DOI: 10.1017/ S0024282918000282 